Systematic Botany (1995), 20(4): pp. 461-481

(c) Copyright 1995 by the American Society of Plant Taxonomists

\title{
A Revision of the Infraspecific Taxonomy of Cyperus esculentus (Yellow Nutsedge) with an Experimentally Evaluated Character Set
}

\author{
PETER SCHIPPERS \\ Department of Theoretical Production Ecology, \\ Agricultural University, P.O. Box 430, 6700 AK Wageningen, The Netherlands \\ SINY J. TER BORG \\ Department of Terrestrial Ecology \& Nature Conservation, Agricultural University, \\ Bornsesteeg 69, 6708 PD Wageningen, The Netherlands
}

\author{
JAN JUST BOS \\ Department of Plant Taxonomy, Agricultural University, P.O. Box 8010, \\ 6700 ED Wageningen, The Netherlands
}

\begin{abstract}
Cyperus esculentus (Yellow Nutsedge) is a troublesome weed with broad infraspecific variation. A growing experiment was performed in which diverse clones were raised under different environmental conditions. Sixty five characters were measured and evaluated based upon their sensitivity to environmental and clonal differences. Of these, 17 proved to be sufficiently reliable for taxonomic purposes. They concern size and shape of floral parts rather than dimensions of spikes, which were until now thought to be the diagnostic characters. Herbarium material from all continents where $C$. esculentus is present was studied, including type material of varieties; 70 plants were selected, the 17 parameters measured, and the data analysed by multivariate techniques. Four clusters were distinguished, which appeared to broadly represent four varieties described by Kükenthal in 1935; three of his seven varieties were rejected, var. cyclolepis, var. nervoso-striatus, and var. sprucei. The four remaining varieties are discussed and described, and a key is given for their identification. They are var. esculentus, var. leptostachyus, var. macrostachyus, and var. heermannii. All of these varieties occur in the Americas as well as in Europe. Variety esculentus dominates in Africa and southern Europe, var. leptostachyus is rather common in both the Old and the New World. Two varieties, var. macrostachyus and var. heermannii, have been recently introduced into the Netherlands; they probably originate from the Americas. The occurrence of var. leptostachyus in Europe is probably the result of an earlier introduction.
\end{abstract}

Cyperus esculentus L., Yellow Nutsedge, is a troublesome perennial weed with a worldwide distribution. It is present on all continents except Antarctica and it is a serious pest in at least 10 countries (Bendixen and Nandihalli 1987). Holm et al. (1977) regarded it as the world's 16 th worst weed. Its range has recently expanded through migrations into N.W. Europe (Rotteveel 1993; Ter Borg and Schippers 1992; Van Groenendael and Habekotté 1988). Although Yellow Nutsedge produces viable seeds, the weed usually spreads by means of the small tubers produced on the rhizomes, and hence a population in a single field may be the progeny of one or only a few genotypes (Horak and Holt 1986).

Although Horak and Holt (1986) found little variation within populations of this clonal spe- cies, morphological variation between populations appeared to be fairly wide. Cyperus esculentus was reported to be variable in respect to a number of agriculturally important characters: e.g., response to herbicides (Costa and Appleby 1976; Hauser 1968; Schippers et al. 1993); tuber size, day length requirements, and aggressiveness related to length and depth of rhizomes (Yip 1978 a, b); susceptibility to winter kill (Matthiesen and Stoller 1978); frost tolerance of tubers and effects of shading (Ter Borg et al. 1988). According to Cavers (1985), the problem of intraspecific variation in weed species will become increasingly important in the near future because of plant introduction and selection by new methods of weed control.

The first study of the infraspecific taxonomy of Yellow Nutsedge was done by Boeckeler 
(1870) who reduced two American species, C phymatodes H.L. Mühl. and C. lutescens Torr. \& Hook. to C. esculentus var. leptostachyus Boeckeler and var. macrostachyus Boeckeler, respectively. Moreover, he recognized a cultivated taxon, C. esculentus var. sativus Boeck. (known as earth almond, tiger nuts, or chufa) which is distinguished by its large edible tubers.

In 1884, Clarke described $C$. esculentus var. sprucei Clarke, and Britton (1886) distinguished var. angustispicatus Britton. The latter author also reduced $C$. heermannii Buckley to $C$. esculentus var. heermannii (Buckley) Britton. Ascherson and Graebner (1902-1904) divided the species in two races: the edible, cultivated sativus, and aureus, including all wild and weedy material. De Vries (1991) proposed cv. Chufa for the cultivated taxon.

In an extensive revision of Cyperaceae, Kükenthal (1935) reviewed the varieties mentioned and described two more, var. nervosostriatus (Turrill) Kük. (= C. nervoso-striatus Turrill) and var. cyclolepis Boeck. ex Kük. Table 1 summarizes the morphological characteristics of the seven weedy varieties he distinguished based on characters of the inflorescence only. Kükenthal's study included herbarium material from North and South America, Africa, southern Europe, the Middle East, and India. Based on Kükenthal's work, var. esculentus has the widest range, with most of the accessions (85) originating from Africa, 16 recorded from North and South America, 22 from southern Europe, two from the Middle East, and nine from India. Two varieties, var. nervoso-striatus and var. cyclolepis were restricted to southern and eastern Africa, and were represented by one and two sheets, respectively. The three other varieties originated from the Americas, with var. leptostachyus the most common (67 citations). Variety macrostachyus, var. sprucei, and var. heermannit were cited 12, six and four times, respectively.

Certain American floras reduced the rank of the taxa, and distinguished a number of forms within var. esculentus [f. esculentus, $\mathrm{f}$. angustispicatus (Britt.) Fern. and f. macrostachyus (Boeckl.) Fern.], with differences mainly based on size of the spikelets (Fernald 1950; Steyermark 1963). Mohlenbrock (1960) maintained the level of variety, included additional characteristics when describing them, and changed their circumscriptions without discussion.

Stoller and Sweet (1987), reviewing the
American literature on physiological and ecological variation within C. esculentus, pointed to problems in classification and indicated several inconsistencies. In a preliminary report on the infraspecific variation of $C$. esculentus in the Netherlands Ter Borg et al. (1988) described four biotypes (A-D), including data on vegetative characters. They had difficulties establishing the taxonomic position of their material.

Since the difficulties of Ter Borg et al. (1988) could be due to plasticity of the characters commonly used for identification, an experimental study was undertaken to evaluate the taxonomic value of a range of morphological characters of C. esculentus. Characters with low sensitivity to environmental variation were considered taxonomically important and were selected for a multivariate numerical analysis. The results formed the basis for an evaluation of the taxa described by Kükenthal (1935), a revision of the infraspecific taxonomy of $C$. esculentus, and an assessment of the geographic distribution of the infraspecific taxa.

\section{MAterials AND MethodS}

Testing Character Reliability. Clones of C. esculentus, raised from single tubers collected in six populations were kept in an experimental garden since 1987. These clones covered the variation observed in the Netherlands and included the four biotypes, A-D, distinguished by Ter Borg et al. (1988). Biotypes A and B were represented by two populations and biotypes $C$ and $\mathrm{D}$ by one each. Voucher specimens collected in the garden are deposited in Herbarium Vadense (WAG) under the following numbers:

A-EK, arable land, S.E. Netherlands, Elsendorp: De Nijs 6001.

A-BT, arable land, S.W. Netherlands, Bath: De Nijs 6301.

B-EW, arable land, S.E. Netherlands, Elsendorp: De Nijs 6701.

B-MB, arable land, N.W. Netherlands, Maartensbrug: De Nijs 4801.

C-MK, arable land, C. Netherlands, Markelo: De Nijs 7401.

D-SB, arable land, S.E. Netherlands, Sambeek: De Nijs 7101.

In March 1990, tubers were taken from one clone each of these six populations and plants 
TABLE 1. Cyperus esculentus varieties according to Kükenthal (1935), " $="$ indicates that this character does not deviate from the state in var. esculentus.

\begin{tabular}{|c|c|c|c|c|c|c|c|}
\hline Character & Esculentus & Cyclolepis & Nerooso-striatus & Macrostachyus & Sprucei & Leptostachyus & Heermannii \\
\hline \multicolumn{8}{|l|}{ Flower } \\
\hline achene & normal & $=$ & broad & $=$ & $=$ & $=$ & $=$ \\
\hline stigmata & normal & $=$ & $=$ & $=$ & long & $=$ & $=$ \\
\hline \multicolumn{8}{|l|}{ Floral scale } \\
\hline form & variable & obovoid & $=$ & obtuse & $=$ & obtuse & obtuse \\
\hline tip & variable & truncate & $=$ & mucronate & $=$ & mucronate & mucronate \\
\hline color & $\begin{array}{l}\text { green-yellow or red- } \\
\text { dish at the edge }\end{array}$ & $=$ & $=$ & brown & yellow-brown & red-brown & red-brown \\
\hline \multicolumn{8}{|l|}{ Spikelet } \\
\hline length $(\mathrm{mm})$ & $5-12$ & $<5$ & $=$ & $\leq 30$ & $\leq 30$ & $15-20$ & $15-20$ \\
\hline width (mm) & 2.0 & $=$ & $=$ & $\leq 3.0$ & $3.0-4.0$ & 1.5 & 1.5 \\
\hline flowers/spikelet & $8-16$ & $4-6$ & $=$ & $\leq 40$ & $\leq 48$ & $=$ & $=$ \\
\hline imbrication & normal & $=$ & $=$ & close & loose & loose & loose \\
\hline form & normal & oval & $=$ & $=$ & $=$ & $=$ & $=$ \\
\hline \multicolumn{8}{|l|}{ Spike } \\
\hline spikelets/spike & $5-14$ & $=$ & $=$ & many & $=$ & many & $=$ \\
\hline spikelet angle & normal & $=$ & $=$ & $=$ & $=$ & $=$ & small \\
\hline spikelet density & low & $=$ & high & $=$ & $=$ & $=$ & very high \\
\hline involucral secondary bracts & no & $=$ & $=$ & $=$ & $=$ & $=$ & yes \\
\hline \multicolumn{8}{|l|}{ Culm, Bracts, and Inflorescence } \\
\hline inflorescence & simple-complex & $=$ & $=$ & $=$ & $=$ & complex & complex \\
\hline culm compressed & yes & $=$ & $=$ & no & $=$ & $=$ & $=$ \\
\hline number of primary bracts & $3-6$ & $=$ & $=$ & $=$ & $=$ & $=$ & $9-13$ \\
\hline number of rays & $5-10$ & $=$ & $=$ & $=$ & $=$ & $=$ & $11-13$ \\
\hline
\end{tabular}


TABLE 2. Cyperus esculentus L. morphological characters scored; also see Fig. 1.

\begin{tabular}{|c|c|}
\hline Designation & Character description \\
\hline \multicolumn{2}{|l|}{ Flower } \\
\hline F1 & Length of the stylar branch. \\
\hline F2 & $\begin{array}{l}\text { Length of the undivided part of } \\
\text { the style. }\end{array}$ \\
\hline F3 & Length of ovary. \\
\hline $\mathrm{F} 4$ & Width of ovary. \\
\hline F5 & $\begin{array}{l}\text { Distance from the base of the } \\
\text { ovary to the place where the } \\
\text { ovary has its maximum width. }\end{array}$ \\
\hline F6 & $\begin{array}{l}\text { Length of the anthers in fully } \\
\text { developed flower. }\end{array}$ \\
\hline F7 & $\begin{array}{l}\text { Length of the filament in fully } \\
\text { developed flower. }\end{array}$ \\
\hline F8 & $\begin{array}{l}\text { Ratio between stylar branch and } \\
\text { glume length (F1/G10). }\end{array}$ \\
\hline F9 & $\begin{array}{l}\text { Ratio between filament and } \\
\text { glume length (F7/G10). }\end{array}$ \\
\hline F10 & $\begin{array}{l}\text { Width/length ratio of the ovary } \\
\text { (F4/F3). }\end{array}$ \\
\hline F11 & $\begin{array}{l}\text { Ratio between stylar branch and } \\
\text { style (F1/F2). }\end{array}$ \\
\hline \multicolumn{2}{|c|}{ Floral scale } \\
\hline $\mathrm{G} 1$ & $\begin{array}{l}\text { Length of a floral scale near the } \\
\text { top of a spikelet. }\end{array}$ \\
\hline $\mathrm{G} 2$ & $\begin{array}{l}\text { Length of a floral scale in the } \\
\text { middle of a spikelet. }\end{array}$ \\
\hline G3 & $\begin{array}{l}\text { Length of a floral scale near the } \\
\text { base of a spikelet. }\end{array}$ \\
\hline G4 & $\begin{array}{l}\text { Maximum width of a floral scale } \\
\text { in the middle of a spikelet } \\
\text { measured from the side of the } \\
\text { floral scale to the midnerve } \times \\
2 \text {. }\end{array}$ \\
\hline G5 & $\begin{array}{l}\text { Distance from the base of a floral } \\
\text { scale to the place where it has } \\
\text { its maximum width. }\end{array}$ \\
\hline G6 & $\begin{array}{l}\text { Ratio between floral scale length } \\
\text { at the base of the spikelet and } \\
\text { mean floral scale length (G3/ } \\
\text { G10). }\end{array}$ \\
\hline G7 & $\begin{array}{l}\text { Width / length ratio of the floral } \\
\text { scale (G4/G2). }\end{array}$ \\
\hline G8 & $\begin{array}{l}\text { Ratio between height where the } \\
\text { floral scale reaches its maxi- } \\
\text { mum width and length of a } \\
\text { floral scale (G5/G2). }\end{array}$ \\
\hline G9 & $\begin{array}{l}\text { Ratio between length of a floral } \\
\text { scale at the top of the spikelet } \\
\text { and the mean length of the } \\
\text { floral scales (G1/G10). }\end{array}$ \\
\hline G10 & $\begin{array}{l}\text { Mean floral scale length } \\
{[(G 1+G 2+G 3) / 3]}\end{array}$ \\
\hline
\end{tabular}

TABLE 2. Continued.

\begin{tabular}{|c|c|}
\hline Designation & Character description \\
\hline \multicolumn{2}{|l|}{ Spikelet } \\
\hline S1 & $\begin{array}{l}\text { Number of scales of spikelet } \\
\text { number } 1 \text { (spikelet selected at } \\
\text { random). }\end{array}$ \\
\hline S2 & $\begin{array}{l}\text { Number of scales of spikelet } \\
\text { number } 2 \text { (spikelet selected at } \\
\text { random). }\end{array}$ \\
\hline S3 & $\begin{array}{l}\text { Number of scales of spikelet } \\
\text { number } 3 \text { (spikelet selected at } \\
\text { random). }\end{array}$ \\
\hline S4 & Length of spikelet number 3. \\
\hline S5 & $\begin{array}{l}\text { Width of spikelet number } 3 \text { at } 1 \\
\text { mm from the top. }\end{array}$ \\
\hline S6 & $\begin{array}{l}\text { Width of spikelet number } 3 \text { mea- } \\
\text { sured in the middle. }\end{array}$ \\
\hline S7 & $\begin{array}{l}\text { Width of spikelet number } 3 \text { at } \\
\text { the base. }\end{array}$ \\
\hline S8 & Thickness of a spikelet. \\
\hline S9 & $\begin{array}{l}\text { Length of a prophyll of a spike- } \\
\text { let. }\end{array}$ \\
\hline S10 & Length of a bract of a spikelet. \\
\hline S11 & $\begin{array}{l}\text { Ratio between spikelet prophyll } \\
\text { and bract (S9/S10). }\end{array}$ \\
\hline S12 & $\begin{array}{l}\text { Ratio between scale angle (top of } \\
\text { spikelet) and mean scale angle } \\
\text { (S15/S19). }\end{array}$ \\
\hline $\mathrm{S} 13$ & $\begin{array}{l}\text { Ratio between scale angle (mid- } \\
\text { dle of spikelet) and mean scale } \\
\text { angle (S16/S19). }\end{array}$ \\
\hline S14 & $\begin{array}{l}\text { Ratio between scale angle (base } \\
\text { of spikelet) and mean scale an- } \\
\text { gle (S17/S19). }\end{array}$ \\
\hline S15 & $\begin{array}{l}\text { Floral scale angle near the top of } \\
\text { a spikelet }(\times=\text { multiplication }) \text {. } \\
{[(360 / 2 \pi) \times \text { ARCSIN }(0.5 \times \text { S5/ }} \\
\text { G1)]. }\end{array}$ \\
\hline S16 & $\begin{array}{l}\text { Floral scale angle at the middle } \\
\text { of a spikelet }[(360 / 2 \pi) \times \\
\text { ARCSIN }(0.5 \times 56 / G 2)]\end{array}$ \\
\hline S17 & 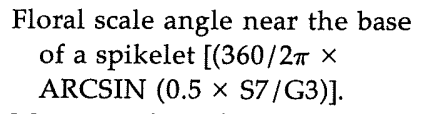 \\
\hline S18 & $\begin{array}{l}\text { Mean number of scales per } \\
\text { spikelet }[(\mathrm{S} 1+\mathrm{S} 2+\mathrm{S} 3) / 3]\end{array}$ \\
\hline S19 & $\begin{array}{l}\text { Mean scale angle } \\
\qquad[(\mathrm{S} 15+\mathrm{S} 16+\mathrm{S} 17) / 3] .\end{array}$ \\
\hline S20 & $\begin{array}{l}\text { Density of floral scales on a } \\
\text { spikelet [S3/(S4-G2)]. }\end{array}$ \\
\hline \multicolumn{2}{|l|}{ Spike } \\
\hline E1 & $\begin{array}{l}\text { Number of primary rays per } \\
\text { plant, including the smallest } \\
\text { visible. }\end{array}$ \\
\hline
\end{tabular}


TABLE 2. Continued.

\begin{tabular}{|c|c|}
\hline Designation & Character description \\
\hline E2 & $\begin{array}{l}\text { Maximum length of a primary } \\
\text { ray from the base to the top of } \\
\text { the spikelet. }\end{array}$ \\
\hline E3 & $\begin{array}{l}\text { The second maximum length of } \\
\text { the primary rays. }\end{array}$ \\
\hline E4 & $\begin{array}{l}\text { Maximum number of spikelets } \\
\text { per spike. }\end{array}$ \\
\hline E5 & $\begin{array}{l}\text { Maximum number of spikelets of } \\
\text { the second order rays per } \\
\text { spike. }\end{array}$ \\
\hline E6 & $\begin{array}{l}\text { Number of second order rays per } \\
\text { spike. }\end{array}$ \\
\hline E7 & Maximum length of the rachis. \\
\hline E8 & $\begin{array}{l}\text { Angle between spikelets and ra- } \\
\text { chis. }\end{array}$ \\
\hline E9 & $\begin{array}{l}\text { Spikelet density on a spike } \\
{[(\mathrm{E} 4+\mathrm{E} 5) / \mathrm{E} 7]}\end{array}$ \\
\hline E10 & $\begin{array}{l}\text { Ratio between number of rays } \\
\text { and culm thickness (E1/C7). }\end{array}$ \\
\hline \multicolumn{2}{|c|}{ Culm and bracts } \\
\hline $\mathrm{C} 1$ & Length of the culm. \\
\hline $\mathrm{C} 2$ & Maximum length of the bracts. \\
\hline $\mathrm{C} 3$ & $\begin{array}{l}\text { Second maximum length of the } \\
\text { bracts. }\end{array}$ \\
\hline $\mathrm{C} 4$ & $\begin{array}{l}\text { Third maximum length of the } \\
\text { bracts. }\end{array}$ \\
\hline C5 & $\begin{array}{l}\text { Width of the largest bract at } 5 \\
\mathrm{~cm} \text { from the base. }\end{array}$ \\
\hline C6 & $\begin{array}{l}\text { Thickness of the largest bract at } \\
5 \mathrm{~cm} \text { from the base. }\end{array}$ \\
\hline $\mathrm{C} 7$ & $\begin{array}{l}\text { Maximum thickness of the culm } \\
5 \mathrm{~cm} \text { under the inflorescence. }\end{array}$ \\
\hline $\mathrm{C} 8$ & $\begin{array}{l}\text { Number of bracts, including the } \\
\text { smallest visible. }\end{array}$ \\
\hline C9 & $\begin{array}{l}\text { Ratio between culm length and } \\
\text { width }(\mathrm{C} 1 / \mathrm{C} 7) \text {. }\end{array}$ \\
\hline $\mathrm{C} 10$ & $\begin{array}{l}\text { Ratio between bract width and } \\
\text { culm width }(\mathrm{C} 5 / \mathrm{C} 7) \text {. }\end{array}$ \\
\hline C11 & $\begin{array}{l}\text { Number of rays/number of } \\
\text { bracts (both including the } \\
\text { smallest visible) (E1/C8). }\end{array}$ \\
\hline \multicolumn{2}{|l|}{ Leaves } \\
\hline L1 & Length of the longest leaf. \\
\hline L2 & $\begin{array}{l}\text { Length of the second-longest } \\
\text { leaf. }\end{array}$ \\
\hline L3 & Length of the third-longest leaf. \\
\hline
\end{tabular}

were grown in greenhouses in 3-liter pots with a soil mixture of $75 \%$ sand and $25 \%$ potting compost. Growth conditions for these greenhouse plants from April 27 to August 7 in Wageningen were varied as follows: soil fertility $(0.318 \mathrm{~g}$ $\mathrm{N} /$ pot and no $\mathrm{N}$ application), temperature $\left(22^{\circ} \mathrm{C}\right.$ and $18^{\circ} \mathrm{C}$ constant temperature) and daylength (natural long days, natural daylengths for one month changed to 12-hour cycles of light and dark for the remainder of the season, and 12hour cycles of light and dark during the entire growing season). An additional set of plants from each of the six populations was grown in outdoor experimental plots under natural conditions in Wageningen during the season of 1987. These natural outdoor conditions were considered a separate treatment, yielding eight treatments in total.

Plants were harvested and dried after flowering. From each treatment and each clone, at least one flowering primary shoot, if available, was chosen along with the smallest (flowering) secondary shoot. Shoot status (i.e., primary or secondary shoot) was considered a further variable to be tested. Forty characters were measured, including those used by Kükenthal (1935), as indicated in Table 2. However, form and color of spikelets were difficult to assess quantitatively and were not studied. Another 24 characters were calculated and derived from the 40 primary values, yielding a total of 65 variables. These almost exclusively concern characters of the inflorescence (Fig. 1; Table 2).

Analysis of variance was performed for unbalanced design to test character dependence on genetic background, environmental conditions, and shoot status. Data were analysed using the GLM procedure of the SAS 6.0 statistical package (SAS Institute Inc. 1985).

Clustering and Ordination. Herbarium material was studied from two main sources.

1) About $1,000 \mathrm{C}$. esculentus vouchers from various herbaria $(\mathrm{B}, \mathrm{BM}, \mathrm{K}, \mathrm{L}, \mathrm{MO}, \mathrm{PRE}$, US, WAG) were examined. After an initial review, 50 of them, from 41 populations covering the range of variation on a global scale and usually cited by Kükenthal (1935), were selected for numerical analysis. This group included the range of variation described by Kükenthal, and the type material of five varieties: var. heermannii, var. sprucei, var. cyclolepis, var. macrostachyus, and var. nervoso-striatus.

2) In the Netherlands 136 inflorescences were collected from the field or from plants grown in pots in the greenhouse or the experimental garden. They were dried and deposited in Herbarium Vadense (WAG). Of these, 20 that cov- 
TABLE 3. Cyperus esculentus plants measured. Identifications according to Kükenthal (1935). ES = var. esculentus, $\mathrm{LE}=$ var. leptostachyus, $\mathrm{MA}=$ var. macrostachyus, $\mathrm{HE}=$ var. heermannii, $\mathrm{NE}=$ var. nervoso-striatus, CY $=$ var. cyclolepis and SP = var. sprucei. A, B, C, and D are biotypes described by Ter Borg et al. (1988), (1) $=$ determined by Kükenthal but not mentioned in Kükenthal (1935); (2) = determined by other authors; (3) $=$ type material.

\begin{tabular}{|c|c|c|c|c|c|}
\hline \multirow{2}{*}{$\begin{array}{c}\text { Popu- } \\
\text { lation } \\
\text { number }\end{array}$} & \multicolumn{2}{|c|}{ Origin } & \multirow{2}{*}{$\begin{array}{c}\text { Number } \\
\text { of } \\
\text { plants }\end{array}$} & \multirow{2}{*}{$\begin{array}{c}\text { Identifi- } \\
\text { cation }\end{array}$} & \multirow[b]{2}{*}{ Collector numbers and herbarium } \\
\hline & Continent, Country & Place & & & \\
\hline 1 & Eu. Netherlands & Elsendorp $\mathrm{K}$ & 3 & A & De Nijs 6010, 6045, 6052 (WAG) \\
\hline 2 & Eu. Netherlands & Elsendorp L & 4 & B & De Nijs 6908-6911 (WAG) \\
\hline 3 & Eu. Netherlands & Elsendorp S & 1 & D & De Nijs 5808 (WAG) \\
\hline 4 & Eu. Netherlands & Elsendorp A & 3 & $\mathrm{C} / \mathrm{B}$ & De Nijs $7005,7018,7020$ (WAG) \\
\hline 5 & Eu. Netherlands & Oosterland & 1 & A & De Nijs 6114 (WAG) \\
\hline 6 & Eu. Netherlands & Maartensbrug & 1 & B & De Nijs 3540 (WAG) \\
\hline 7 & Eu. Netherlands & Boxmeer & 3 & $\mathrm{D}$ & De Nijs 7101, 7104, 7109 (WAG) \\
\hline 8 & Eu. Netherlands & Markelo & 4 & $C / D$ & De Nijs $7407,7415,7417,7418$ (WAG) \\
\hline 50 & Eu. Turkey & Pontus & 1 & ES & Sintenis $1417(\mathrm{~K})$ \\
\hline 51 & Eu. France & Mentone & 2 & ES & Moggridge s.n. (US) \\
\hline 52 & Eu. France & Corsica & 1 & ES & Mabile $285(\mathrm{~K})$ \\
\hline 53 & Eu. Spain & Segorbe & 1 & ES & Reverchon s.n. (US) \\
\hline 54 & Eu. Italy & Napoli & 2 & ES & Tenore s.n. (K) \\
\hline 55 & Eu. Italy & Palermo & 1 & ES & Todaro s.n. (K) \\
\hline 56 & Af. Zimbabwe & Cheshire & 1 & ES & $\begin{array}{l}\text { Exped. Suecica in Africam, } \\
\text { Austr. et Rhodesiam } 4424 \text { (BM) }\end{array}$ \\
\hline 57 & Af. Ethiopia & Tigre & 1 & ES & Schimper 1246 (BM) \\
\hline 58 & Af. Egypt & Damiette & 1 & ES & Sieber $393(\mathrm{~K})$ \\
\hline 59 & Af. Tanzania & Malongwe & 1 & ES & Peter $34633(\mathrm{~K})$ \\
\hline 60 & Af. Sierra Leone & Niger (river) & 1 & ES & Vogel $31(\mathrm{~K})$ \\
\hline 61 & Af. Senegal & $?$ & 1 & ES & Trochain $171(\mathrm{~K})$ \\
\hline 62 & Af. Central Afr. & Bambari & 1 & ES & Tisserant $1503(\mathrm{~K})$ \\
\hline 63 & Af. Tanzania & Kilimandscharo & 1 & ES & Volkens $2111(\mathrm{~K})$ \\
\hline 64 & Af. Tanzania & Ruhudje (river) & 1 & ES & Schlieben 1931 (K) \\
\hline 65 & Af. Mozambique & Zambesia & 1 & ES & Buchanan $23(\mathrm{~K})$ \\
\hline 66 & Af. South Afr. & Pretoria & 3 & $\mathrm{CY}(3)$ & Rehmann 4776 (B, K) \\
\hline 67 & Af. South Afr. & Ermelo & 1 & $\mathrm{NE}(3)$ & Burtt-Davy 9237 (PRET) \\
\hline 68 & NA. California & $?$ & 2 & $\mathrm{HE}(3)$ & Heermann s.n. (US) \\
\hline 69 & NA. Utah & Moab & 1 & $\mathrm{HE}(2)$ & Parrish s.n. (US) \\
\hline 70 & NA. Texas & $?$ & 3 & $\mathrm{MA}(3)$ & Drummond $452(\mathrm{~B}, \mathrm{BM}, \mathrm{K})$ \\
\hline 71 & NA. Texas & El Paso & 1 & MA & Wright 705 (BM) \\
\hline 72 & NA. California & San Diego & 1 & MA & Orcutt 1314 (US) \\
\hline 73 & NA. Florida & Duval Co. & 3 & LE & Curtiss 3052 (K, US) \\
\hline 74 & NA. Missouri & St. Louis & 1 & LE & Drummond 61 (B) \\
\hline 75 & NA. Illinois & Bornizet? & 1 & $\mathrm{LE}(1)$ & Anon. s.n. (B) \\
\hline 76 & NA. Mississippi & New Orleans & 1 & LE & Drummond 387 (B) \\
\hline 77 & NA. Missouri & St. Louis & 1 & $\mathrm{LE}(1)$ & Eggert s.n. (B) \\
\hline 78 & NA. California & Sacramento & 1 & LE & Jones 3529 (BM) \\
\hline 79 & NA. Oklahoma & Tishomingo & 1 & LE & Palmer 6454 (US) \\
\hline 80 & NA. Texas & Comanche Spring & 1 & ES & Lindheimer $1237(\mathrm{~K})$ \\
\hline 81 & CA. Dominican Rep. & Santo Domingo & 1 & LE & Ekman $14084(\mathrm{~K})$ \\
\hline 82 & CA. Haiti & Vaillecite & 1 & LE & Ekman 6103 (US) \\
\hline 83 & CA. Mexico & Morelia & 1 & LE & Arsène 5231 (BM) \\
\hline 84 & CA. Mexico & Orizaba & 1 & ES & Bourgeau 2386 (US) \\
\hline 85 & CA. Mexico & Rancho Pasadat & 1 & ES & Nicolas s.n. (US) \\
\hline 86 & CA. Mexico & Guadahyze & 1 & ES & Bourgeau 526 (US) \\
\hline 87 & SA. Paraguay & Rica & 1 & $\mathrm{LE}(1)$ & Jörgensen 3575 (B) \\
\hline 88 & SA. Brazil & Pardo & 1 & $\mathrm{LE}(1)$ & Jurgens 97 (B) \\
\hline 89 & SA. Ecuador & Chanduy & 1 & $\mathrm{SP}(3)$ & Spruce $6414(\mathrm{~K})$ \\
\hline 90 & AS. India & Madras & 1 & ES & Thomson $69(\mathrm{~K})$ \\
\hline
\end{tabular}


ered the range of morphologic variation observed in the Netherlands were selected for detailed measurements. They represent eight populations.

The 70 plants selected for this study (Table 3) were screened for the characters chosen according to the results of the experimental evaluation. Data were standardized and preprocessed with the ACECLUS procedure of the SAS statistical package. Canonical variables from this procedure were used for clustering and ordination. Relationships among the plants were analyzed with Wards minimum variance method of the CLUSTER procedure (SAS Institute Inc. 1985).

Results of the clustering analysis were compared with the classification by Kükenthal (1935) and the geographic origin of the selected plants. The characters of contradictory specimens were compared, and individual plants were reclassified as necessary. Based on this analysis, descriptions of four varieties were revised and their geographic distribution indicated.

\section{RESULTS}

Character Reliability. Clones did not flower in every situation. Clones A-EK and C-MK flowered under all conditions, except short days, where none of the clones produced an inflorescence. Shoots of clone C-MK did not grow under short day conditions, but did produce a few tubers. Clones B frequently produced flowers under higher temperatures; under other conditions B usually produced a culm with bracts only. Fifty-three flowering shoots were harvested and their data used for statistical analysis.

Table 4 summarizes the results of the analysis of variance. In 44 out of 65 cases, characters differed significantly between clones, and 31 characters were shown to be sensitive to environmental variation or shoot status. Based on these results four groups of characters were distinguished.

Group 1 includes the most important characters, since they differ significantly between clones and are stable with respect to variable growing conditions and shoot status. The characters in group 2 vary between clones also, but they are affected by environmental conditions and shoot status and can be useful only when the effect of clonal background is high com-

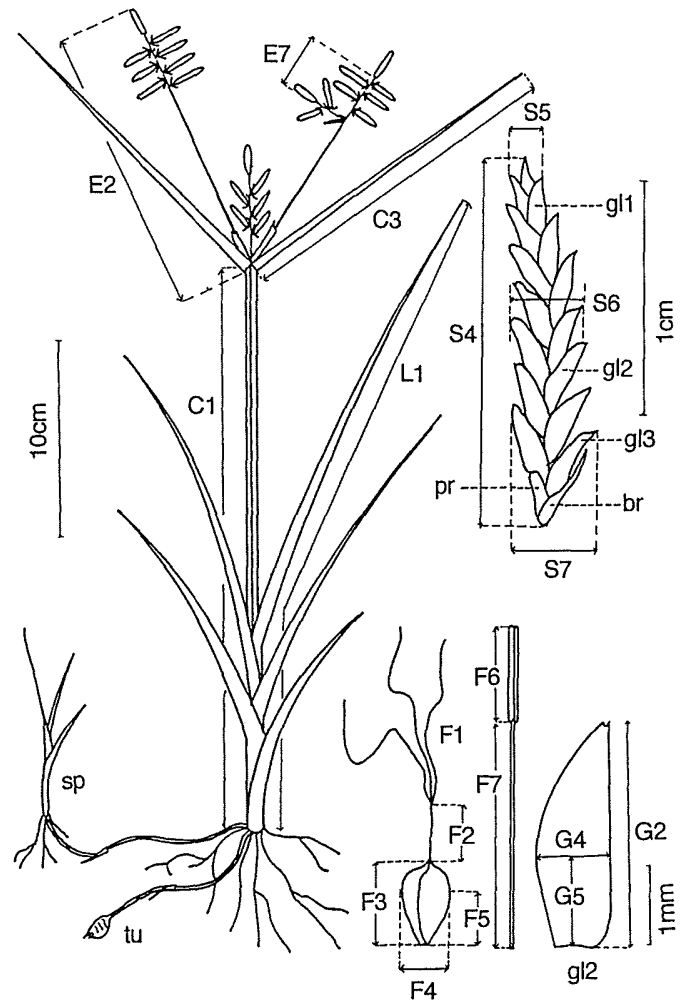

FIG. 1. Schematic drawing of Cyperus esculentus showing some characters described in Table 4. gl1, g12 and gl3 = floral scales (glumes) from which characters G1, G2 and G3 have been measured; pr = prophyll, $\mathrm{br}=$ bract of a spikelet from which $\mathrm{S10}$ was measured, $\mathrm{sp}=$ secondary shoot, $\mathrm{tu}=$ tuber.

pared to other sources of variation. However, under uniform conditions these characters can be as important as characters of group 1 .

Group 3 consists of characters that show no significant differences and therefore can not be used in distinguishing the clones included in this experiment. However, they can be excellent characters separating other clones. Characters in group 4 have no taxonomic value. They did not differ among the clones studied; their variation is due to other factors.

Characters were chosen for further taxonomic treatment using the following criteria: 1) high between-clone variation compared to variation caused by environmental differences or shoot status, and 2) low suspected dependence upon other selected characters. Seventeen characters indicated in Table 4 were selected, 13 from group 1 , three from group 2, and one from group 3. 
TABLE 4. $F$ values in the analysis of variance, testing the effect of clonal origin, environmental conditions, and shoot status on morphological characters of Cyperus esculentus $\left({ }^{*} P<0.01 ;{ }^{* *} P<0.001 ;{ }^{* *} P<0.0001\right)$. $(S)=$ characters selected for numerical analysis. $(K)=$ characters used by Kükenthal (1935).

\begin{tabular}{|c|c|c|c|c|c|}
\hline \multirow[b]{2}{*}{ Designation } & \multicolumn{2}{|c|}{ Source of variation } & \multirow[b]{2}{*}{$\begin{array}{l}\text { Shoot status } \\
\text { d.f. }=1 \\
\text { F value }\end{array}$} & \multirow[b]{2}{*}{$\begin{array}{c}\text { Characters } \\
\text { selected }\end{array}$} & \multirow[b]{2}{*}{$\begin{array}{l}\text { Used by } \\
\text { Kükenthal (1935) }\end{array}$} \\
\hline & $\begin{array}{l}\text { Clone } \\
\text { d.f. }=5 \\
F \text { value } \\
\end{array}$ & $\begin{array}{l}\text { Environment } \\
\text { d.f. }=6 \\
F \text { value }\end{array}$ & & & \\
\hline \multicolumn{6}{|c|}{ Group 1 Characters } \\
\hline G5 & $39.22^{* * *}$ & 0.11 & 0.20 & (S) & - \\
\hline G4 & $35.27^{* * *}$ & 2.73 & 2.63 & (S) & - \\
\hline F1 & $33.46^{* * *}$ & 1.41 & 0.05 & (S) & $(\mathrm{K})$ \\
\hline C11 & $23.47^{* * *}$ & 0.89 & 3.32 & (S) & - \\
\hline E10 & $21.80^{* * *}$ & 1.43 & 0.02 & - & - \\
\hline s1 & $20.69^{* * *}$ & 1.86 & 6.93 & (S) & $(\mathrm{K})$ \\
\hline S19 & $20.45^{* * *}$ & 1.05 & 4.11 & - & - \\
\hline E6 & $18.52^{* * *}$ & 2.22 & 4.10 & (S) & $(\mathrm{K})$ \\
\hline E9 & $16.37^{* * *}$ & 0.79 & 1.68 & (S) & $(\mathrm{K})$ \\
\hline S2 & $15.40^{* * *}$ & 2.54 & 6.66 & - & - \\
\hline F7 & $14.09^{* * *}$ & 1.63 & 0.40 & - & - \\
\hline E8 & $12.91^{* * *}$ & 2.26 & 4.80 & (S) & $(\mathrm{K})$ \\
\hline S16 & $10.51^{* * *}$ & 0.55 & 0.01 & (S) & - \\
\hline S15 & $10.03^{* * *}$ & 0.88 & 0.60 & - & - \\
\hline S11 & $8.62^{* * *}$ & 1.66 & 0.20 & (S) & - \\
\hline $\mathrm{F} 2$ & $8.05^{* * *}$ & 0.52 & 1.47 & (S) & - \\
\hline E5 & $7.64^{* * *}$ & 2.01 & 3.24 & - & - \\
\hline S10 & $6.29^{* *}$ & 2.30 & 4.63 & - & - \\
\hline F9 & $5.51^{* *}$ & 2.45 & 1.19 & - & - \\
\hline F11 & $5.07^{*}$ & 1.30 & 0.96 & - & - \\
\hline $\mathrm{S} 12$ & $4.32^{*}$ & 0.99 & 0.01 & - & - \\
\hline G7 & $4.12^{*}$ & 2.58 & 0.08 & - & - \\
\hline G9 & $3.83^{*}$ & 3.01 & 0.26 & (S) & - \\
\hline $\mathrm{F} 6$ & $3.69^{*}$ & 1.46 & 2.13 & (S) & - \\
\hline \multicolumn{6}{|c|}{ Group 2 Characters } \\
\hline G10 & $72.98^{* * *}$ & $8.47^{* * *}$ & 2.65 & (S) & - \\
\hline G1 & $68.14^{* * *}$ & $10.71^{* * *}$ & 1.27 & - & - \\
\hline G2 & $57.63^{* * *}$ & $6.97^{* * *}$ & 4.01 & - & - \\
\hline $\mathrm{S} 20$ & $51.66^{* * *}$ & $10.05^{* * *}$ & 3.03 & (S) & $(\mathrm{K})$ \\
\hline G3 & $31.77^{* * *}$ & $3.97^{*}$ & 0.90 & - & - \\
\hline S3 & $18.58^{* * *}$ & 2.06 & $7.67^{*}$ & - & - \\
\hline E1 & $17.06^{* * *}$ & 2.45 & $22.42^{* * *}$ & - & - \\
\hline E7 & $14.43^{* * *}$ & $3.66^{*}$ & $30.19 * * *$ & - & - \\
\hline 54 & $13.09^{* * *}$ & 3.27 & $9.05^{*}$ & - & (K) \\
\hline S18 & $12.39^{* * *}$ & 3.01 & $7.60^{*}$ & - & $(\mathrm{K})$ \\
\hline S17 & $11.35^{* * *}$ & 1.93 & $10.76^{*}$ & - & - \\
\hline F8 & $10.24^{* * *}$ & $5.28^{* *}$ & 1.11 & - & - \\
\hline s9 & $9.48^{* * *}$ & $3.89^{*}$ & $10.90^{*}$ & - & - \\
\hline G8 & $6.95^{* * *}$ & $3.42^{*}$ & 3.39 & - & - \\
\hline E4 & $6.53^{* *}$ & $5.61^{* *}$ & $30.40^{* * *}$ & - & $(\mathrm{K})$ \\
\hline $\mathrm{C} 2$ & $5.68^{* *}$ & $40.57^{* * *}$ & $63.25^{* * *}$ & - & - \\
\hline $\mathrm{C} 8$ & $4.85^{*}$ & $4.66^{*}$ & $37.91^{* * *}$ & - & $(\mathrm{K})$ \\
\hline L1 & $4.42^{*}$ & $53.15^{* * *}$ & $67.76^{* * *}$ & - & - \\
\hline $\mathrm{C} 9$ & $4.18^{*}$ & $20.97^{* * *}$ & 1.32 & - & - \\
\hline G6 & $4.12^{*}$ & $3.54^{*}$ & 0.98 & (S) & - \\
\hline
\end{tabular}


TABLE 4. Continued.

\begin{tabular}{|c|c|c|c|c|c|}
\hline \multirow[b]{2}{*}{ Designation } & \multicolumn{2}{|c|}{ Source of variation } & \multirow[b]{2}{*}{$\begin{array}{l}\text { Shoot status } \\
\text { d.f. }=1 \\
F \text { value }\end{array}$} & \multirow[b]{2}{*}{$\begin{array}{l}\text { Characters } \\
\text { selected }\end{array}$} & \multirow[b]{2}{*}{$\begin{array}{l}\text { Used by } \\
\text { Kükenthal (1935) }\end{array}$} \\
\hline & $\begin{array}{l}\text { Clone } \\
\text { d.f. }=5 \\
F \text { value }\end{array}$ & $\begin{array}{l}\text { Environment } \\
\text { d.f. }=6 \\
F \text { value }\end{array}$ & & & \\
\hline \multicolumn{6}{|c|}{ Group 3 Characters } \\
\hline $\mathrm{C} 10$ & 2.70 & 1.13 & 6.48 & - & - \\
\hline F4 & 2.39 & 1.40 & 3.09 & - & (K) \\
\hline S5 & 1.97 & 1.37 & 0.70 & - & - \\
\hline F5 & 1.94 & 2.75 & 1.20 & - & - \\
\hline F10 & 1.87 & 2.78 & 2.93 & (S) & $(\mathrm{K})$ \\
\hline C6 & 1.28 & 1.64 & 2.57 & - & - \\
\hline S14 & 1.21 & 1.61 & 5.18 & - & - \\
\hline S8 & 1.12 & 2.90 & 0.06 & - & - \\
\hline F3 & 0.64 & 2.03 & 0.00 & - & - \\
\hline L3 & 0.55 & 2.68 & 2.91 & - & - \\
\hline \multicolumn{6}{|c|}{ Group 4 Characters } \\
\hline $\mathrm{S} 13$ & 3.41 & 1.43 & $8.40^{*}$ & - & - \\
\hline $\mathrm{C} 1$ & 3.16 & $15.54^{* * *}$ & $22.66^{* * *}$ & - & - \\
\hline S6 & 2.79 & $5.38^{* *}$ & 1.42 & - & (K) \\
\hline L2 & 2.65 & $42.37^{* * *}$ & $58.33 * * *$ & - & - \\
\hline $\mathrm{C} 3$ & 2.35 & $22.42^{* * *}$ & $51.04^{* * *}$ & - & - \\
\hline $\mathrm{C} 7$ & 2.20 & $3.59^{*}$ & $48.80^{* * *}$ & - & $(\mathrm{K})$ \\
\hline S7 & 1.91 & $3.84^{*}$ & $16.65^{* *}$ & - & - \\
\hline E3 & 1.88 & $4.73^{* *}$ & $32.24^{* * *}$ & - & - \\
\hline E2 & 1.78 & $5.63^{* *}$ & $32.50 * * *$ & - & - \\
\hline $\mathrm{C} 4$ & 0.85 & $12.79 * * *$ & $46.90^{* * *}$ & - & - \\
\hline C5 & 0.68 & 2.30 & $21.65^{* * *}$ & - & - \\
\hline
\end{tabular}

Cluster Analysis. Figure 2 presents the results of the cluster analysis of the 70 plants included in this study (Table 3 ). Their classification according to Ter Borg et al. (1988) and Kükenthal (1935) are indicated as well as their geographic origins. The analysis shows four main clusters.

Figure 3 gives the ordination diagrams of the same plants, showing their position according to cluster number (Fig. 3A), taxonomic position (Fig. 3B), or geographic origin (Fig. 3C). There are no distinct clusters in Fig. 3. However, there is a clear relationship between cluster borders and classification (Fig. 3B), and geographic origin (Fig. 3C).

In general the position of plants from the American continents (Fig. 2, clusters 1, 3, and 4 ) is clearly distinct from that of plants from other continents, most of which belong to cluster 2. Only 4 plants did not fit into this pattern (outlined in Fig. 3), viz. Reverchon s.n. (US); Trochain $171(\mathrm{~K})$; Volkens $2111(\mathrm{~K})$; Thomson $69(\mathrm{~K})$; (Table 3, numbers 53,61,63 and 90). These four plants were classified as var. esculentus by Kükenthal and appear to be on the edge of cluster 2 according to the ordination. Therefore it seems to be justified to consider these plants var. esculentus.

All clusters but number 1 were found to be rather homogeneous, and dominated by a single variety; cluster 2 is dominated by var. esculentus, cluster 3 by var. heermannii, and cluster 4 by var. leptostachyus.

Apart for the single exception of De Nijs 7005 (WAG), (Table 3, no. 4), all plants belonging to the four biotypes distinguished in the Dutch material were found grouped, each group in a separate cluster (Fig. 2).

Cluster 1 appears to include four varieties, none of which predominates. Six plants had been identified as var. esculentus by Kükenthal, five as var. macrostachyus, four as var. leptostachyus, and one as var. sprucei. Most of these originate from the Americas and only two from Africa; the latter already have been assigned as var. esculentus. Table 5 gives the data on floral 


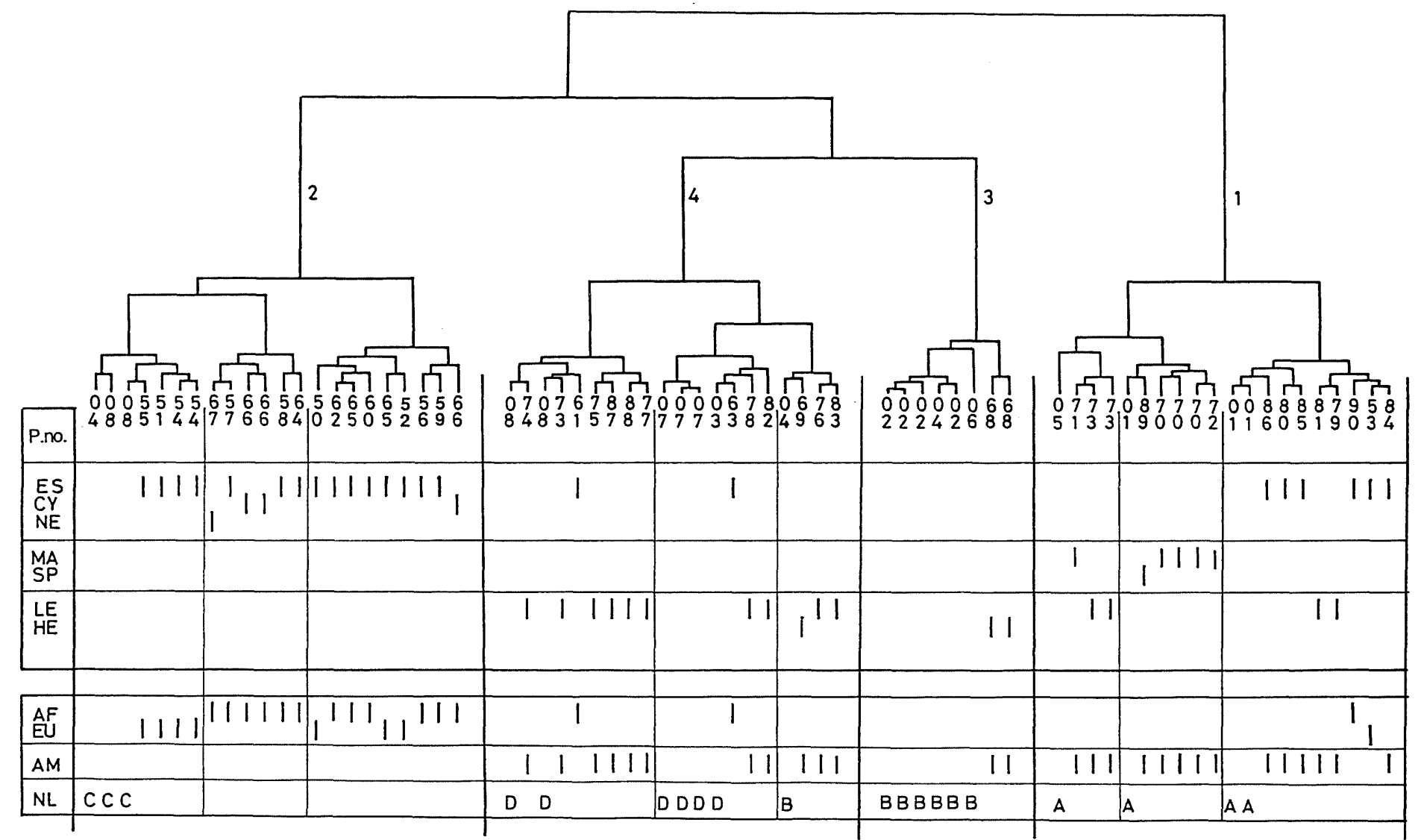

FIG. 2. Dendrogram of 70 Cyperus esculentus plants representing the morphological variation of the studied vouchers. P.no. $=$ population number according to Table 3. Variety according to Kükenthal (1935): ES = var. esculentus, $\mathrm{CY}=$ var. cyclolepis, NE = var. nervoso-striatus, MA $=$ var. macrostachyus, SP = var. sprucei, $\mathrm{LE}=$ var. leptostachyus, $\mathrm{HE}=$ var. heermannii. Geographic origin: $\mathrm{AF}=$ Africa and Asia, $\mathrm{EU}=$ Europe, $\mathrm{AM}=\mathrm{N}$. and $\mathrm{S}$. America, NL = the Netherlands. Biotypes A-D according to Ter Borg et al. (1988). 


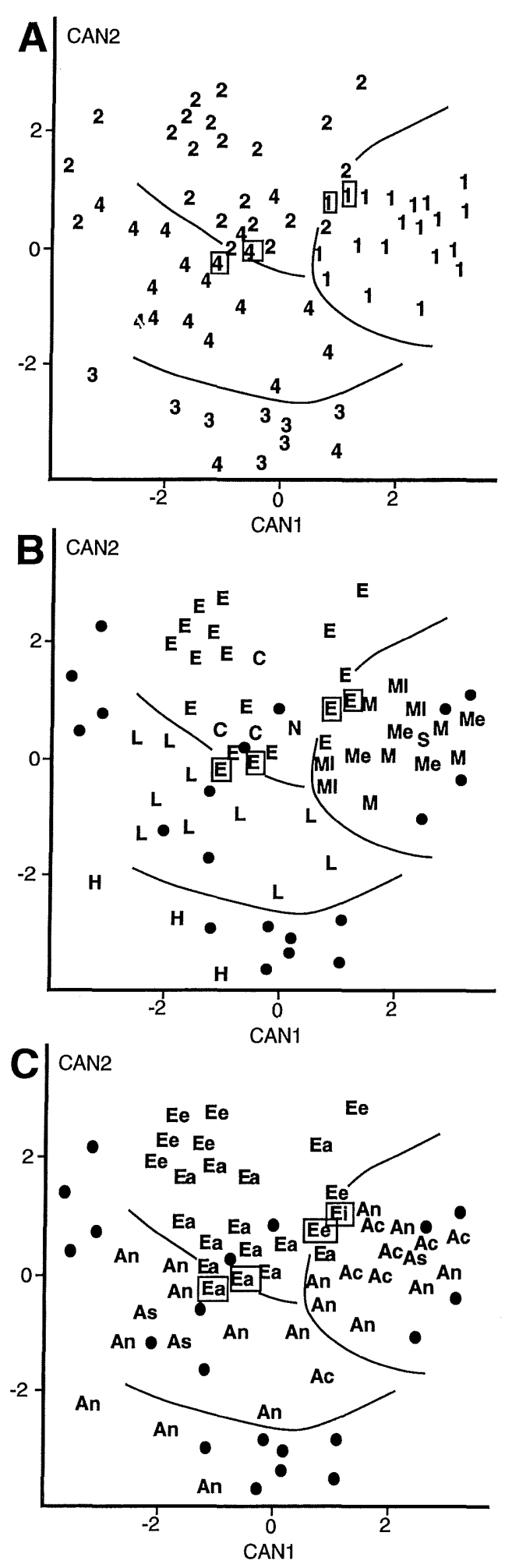

scales and spikelets of the var. esculentus and var. leptostachyus material of cluster 1 , and the mean values of all plants of var. esculentus, var. leptostachyus, and var. macrostachyus measured. It indicates that the floral scale characters of var. leptostachyus and var. esculentus plants in cluster 1 are much more similar to the values observed in var. macrostachyus than to those found in both other varieties. Since floral scale characters were found to be more reliable than characters of spikelets, the plants concerned can be grouped together with var. macrostachyus. Plants belonging to the Dutch biotype A occur in this cluster.

Cluster 2 consists of 22 plants, all of these originating from the Old World (Africa, Europe, and Asia). The majority (16 plants) were identified as var. esculentus. Furthermore this cluster includes the type species of var. nervoso-striatus and var. cyclolepis. Figures $4 \mathrm{~A}$ and $\mathrm{B}$ graphically present the characters measured and show a strong resemblance of the latter varieties to var. esculentus. This cluster includes biotype $\mathrm{C}$ from the Netherlands.

Cluster 3 includes eight plants. The two plants of var. heermannii are the only reference material from Kükenthal assigned to this cluster. Grouped with them are the Dutch biotype B plants except De Nijs 7005 (WAG) (Table 3, no. 4).

Cluster 4 consists of 10 plants of var. leptostachyus and one of var. heermannii, all from the Americas, and two African plants of var. esculentus. The latter plants were already identified as var. esculentus because of their position in the ordination diagram and their determination by Kükenthal. With regard to its position in the ordination diagram (Fig. $3 \mathrm{~B}$ ) the plant of var.

FIg. 3. Ordination diagram of 70 selected Cyperus esculentus plants (first two canonical variables). A. Individual plants indicated by their cluster number in Fig. 2. B. Plants indicated by their variety according to Kükenthal (1935): $\mathrm{C}=$ var. cyclolepis; $\mathrm{E}=$ var. esculentus; $\mathrm{H}=$ var. heermannii; $\mathrm{L}=$ var. leptostachyus; $\mathrm{M}=$ var. macrostachyus $\left(\mathrm{M}_{1}\right.$ and $\mathrm{M}_{\mathrm{e}}$ were considered as var. leptostachyus and var. esculentus resp. by Kükenthal, 1935); $\mathrm{N}=$ var. nervoso-striatus; $\mathrm{S}=$ var. sprucei. C. Plants indicated by their geographic origin: $A_{n}, A_{c}, A_{s}=$ North, Central and South America resp.; $E_{e}=$ Europe, $E_{a}=$ Africa, $E_{i}=$ India. In $B$ and $\mathrm{C} \bullet=$ plants from the Netherlands. Outlined plants are cases discussed in the text. 
TABLE 5. Final determination of American Cyperus esculentus plants of cluster 1, which are erroneously determined by Kükenthal (1935), on floral scale and spikelet dimensions. Measurements (in mm) for G2, G4, G5, S4, and S6 are as described in Table 2 and Fig. 1. Population number according to Table 3. ES = var. esculentus, $\mathrm{LE}=$ var. leptostachyus, and $\mathrm{MA}=$ var. macrostachyus. Origin: $\mathrm{Am}=$ America, $\mathrm{Af}=$ Africa, Europe, Asia.

\begin{tabular}{|c|c|c|c|c|c|c|c|c|c|}
\hline \multirow{2}{*}{$\begin{array}{l}\text { Population } \\
\text { number }\end{array}$} & \multirow{2}{*}{$\begin{array}{l}\text { Number } \\
\text { of plants }\end{array}$} & \multirow{2}{*}{$\begin{array}{l}\text { Determination } \\
\text { Kükenthal } \\
(1935)\end{array}$} & \multirow[b]{2}{*}{ Origin } & \multicolumn{3}{|c|}{ Floral scale } & \multicolumn{2}{|c|}{ Spikelet } & \multirow{2}{*}{$\begin{array}{c}\text { Final } \\
\text { determi- } \\
\text { nation }\end{array}$} \\
\hline & & & & G2 & G4 & G5 & S4 & S6 & \\
\hline 80 & 1 & ES & Am & 3.1 & 2.0 & 1.9 & 18.1 & 1.8 & MA \\
\hline 84 & 1 & ES & Am & 3.0 & 2.1 & 1.5 & 12.2 & 1.7 & MA \\
\hline 85 & 1 & ES & Am & 3.2 & 2.4 & 2.0 & 9.0 & 1.6 & MA \\
\hline 86 & 1 & ES & Am & 3.2 & 2.3 & 2.0 & 12.0 & 2.4 & MA \\
\hline (Mean) & 19 & ES & Af & 2.5 & 1.9 & 1.2 & 11.4 & 2.1 & ES \\
\hline (Mean) & 5 & MA & Am & 3.3 & 2.1 & 1.6 & 37.8 & 2.5 & MA \\
\hline (Mean) & 10 & LE & $\mathrm{Am}$ & 2.2 & 1.6 & 1.1 & 12.7 & 1.2 & LE \\
\hline 73 & 1 & $\mathrm{LE}$ & Am & 3.1 & 2.1 & 1.5 & 22.0 & 1.7 & MA \\
\hline 73 & 1 & LE & $\mathrm{Am}$ & 2.8 & 1.9 & 1.4 & 10.7 & 1.9 & MA \\
\hline 79 & 1 & $\mathrm{LE}$ & Am & 3.5 & 1.9 & 2.0 & 17.0 & 1.7 & MA \\
\hline 81 & 1 & LE & $\mathrm{Am}$ & 3.2 & 2.0 & 1.5 & 12.9 & 2.0 & MA \\
\hline
\end{tabular}

heermannii might as well belong to cluster 3 ; the same holds for the one plant of the Dutch biotype B. Therefore cluster 4 appears to consist exclusively of var. leptostachyus and the six plants of biotype $D$, or nearly so.

\section{DisCUSSION}

Character Evaluation. Seventeen characters were selected as diagnostically useful for the infraspecific taxonomy, as opposed to seven characters used by Kükenthal (1935). Although not used by Kükenthal, dimensions of the floral scale (G10, G4 and G5), are significant characters according to the analysis of variance. Several characters mentioned by Kükenthal (1935) were not included in our analysis. Two were excluded because they were difficult to quantify (shape and color of spikelets) and four more characters, spikelet width (S6), number of spikelets per spike (E4), culm width (C7) and number of bracts (C8) were sensitive to environmental variation or shoot status (Table 4). Spikelet length (S4) was left out because of its logical dependence on two other significant characters, S1 (number of floral scales on a spikelet) and S20 (number of floral scales $/ \mathrm{mm}$ spikelet)

Spikelet length (S4) and width (S6) are the most important characters used by previous authors (Kükenthal 1935; Fernald 1950; Yip 1978) and are included in the descriptions of varieties and sometimes used for their delimitation. Usually exact values are given. According to the analysis of variance, spikelet length (S4) is a group 2 character. It differs significantly $(P<$ $0.0001)$ between clones and between primary and secondary shoots $(P<0.001)$. For environmental conditions $P$ was just over 0.01 (Table 4). Although spikelet length is a relevant character it may vary considerably within one clone (Fig. 5). According to Kükenthal (1935), varieties differ in spikelet lengths as follows: var. esculentus $<1.2 \mathrm{~cm}$, var. leptostachyus and var. heermannii $1.5-2.0 \mathrm{~cm}$, var. sprucei and var. macrostachyus up to $3.0 \mathrm{~cm}$. Figure 5 shows that even plants of a single clone have spikelet

FIG. 4. Characterization of varieties of Cyperus esculentus according to the 17 morphological characters measured. X-axis: mean values of all plants measured $\pm 2 \times$ s.d.; dotted area $=$ mean values $\pm 1 \times$ s.d. (Dutch material not included). A. Var. esculentus; bold line indicates the type material of var. cyclolepis (Rehmann $4776[\mathrm{KJ}])$, average values of three plants on a sheet). B. Var. esculentus; bold line indicates the type plant of var. nervoso-striatus (Burtt-Davy 9237 [PRE]). C. Var. macrostachyus; bold line indicates type plant of var. sprucei (Spruce $6414[\mathrm{~K}]$ ). D. Var. leptostachyus. E. Var. heermannii (mean value of 3 plants). 

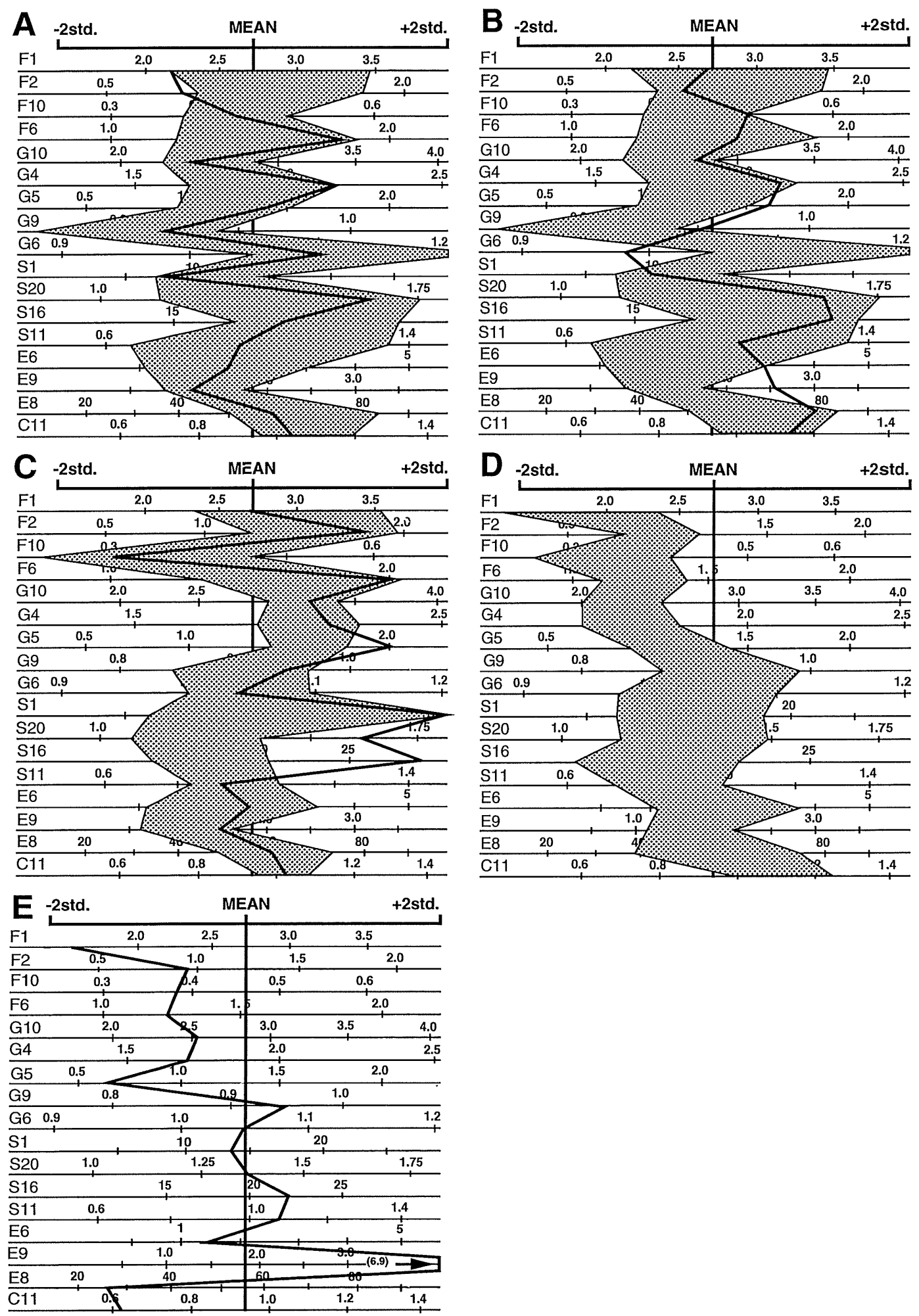


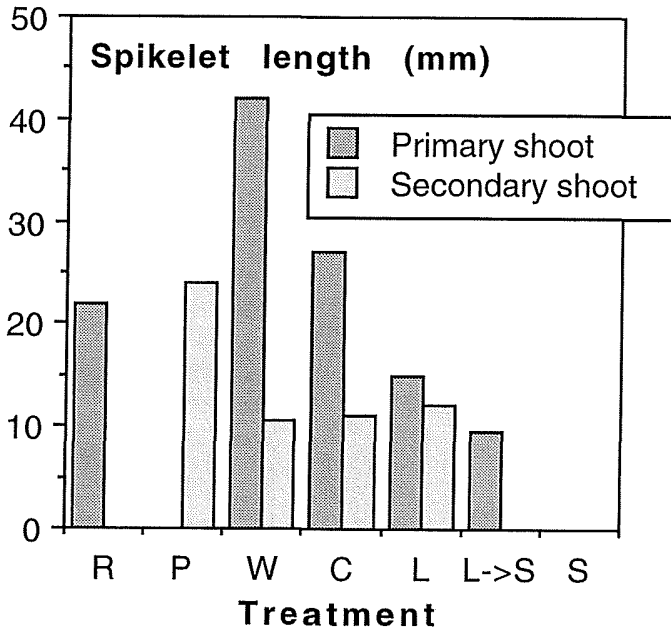

FIG. 5. Spikelet lengths in one clone of Cyperus esculentus (var. macrostachyus) plants grown under widely different conditions. If plants did not flower in a certain treatment no bar is drawn. Treatment conditions are those discussed in MATERIALS AND METHODS, where $\mathrm{R}=$ nitrogen rich, $\mathrm{P}=$ nitrogen poor, $\mathrm{W}=22^{\circ} \mathrm{C}$ constant, $\mathrm{C}=18^{\circ} \mathrm{C}$ constant, $\mathrm{L}=$ natural daylength in the Netherlands (long), $\mathrm{L} \rightarrow \mathrm{S}=$ natural daylength for one month changed to 12-hour cycles of light and dark for the remainder of the season, $S=12$-hour cycles of light and dark during the entire growing season.

lengths in all categories. These results make the use of exact limits between varieties of this character questionable and give reason to doubt the central position of this character in the infraspecific taxonomy of Yellow Nutsedge.

Spikelet width (Table 2, S6) appeared to be sensitive to environmental conditions and no evidence of genetic differences between clones analyzed was found for this character. It is a product of length of floral scales (Table 2, G2) and angle of divergence of floral scales from the rachilla (Table 2, S16), both of which were selected as taxonomically useful characters. Spikelet width itself, however, is not a reliable character for the following reason. Plants analyzed often combined a long floral scale with a narrow angle of divergence, in which case spikelet width was normal (ca. $2 \mathrm{~mm}$ ). Under relatively long dry conditions, however, scale angles increase slightly, with a strong effect on spikelet width, which is expressed as $2 \times \sin$ (scale angle) $\times$ scale-length. This strong effect is especially the case when scales are long and the angle of divergence is normally narrow (e.g., in var. macrostachyus). Therefore spikelet width is an unreliable character, sensitive to drying and other environmental conditions (Table 4), and should not be used in assessing the infraspecific taxonomy of C. esculentus.

Treatment of the Varieties. The results of the numerical analysis show that all four clusters, after minor corrections, are homogeneous, in regard of morphology and geographic origin. They appear to correlate fairly well with taxa distinguished by Kükenthal (1935), who recognized them at the level of varieties. Later authors (e.g., Fernald 1950) reduced them to forms. However, because of the strong relationship between the clusters distinguished and their geographic origin (Fig. 3B, C) recognition at varietal level seems warranted. Moreover, it was found that populations differ with respect to a range of ecological, physiological, and agriculturally important characteristics. This variation appeared to be related to the taxa; therefore, following Kükenthal (1935) and Mohlenbrock (1960), we maintain a varietal classification.

In cluster 1 four varieties identified by Kükenthal are present. However, as indicated above, some of the plants included should be reclassified according to our standards. This leaves cluster 1 with var. macrostachyus and var. sprucei. Table 1 and Fig. $4 \mathrm{C}$ show that the differences between these varieties are very small. Originally var. sprucei was distinguished because of its longer stigmata, yellow-brown floral scales, and slightly wider spikelets (Table 1). However, Fig. $4 \mathrm{C}$ shows that all but two characters of the type specimen of var. sprucei (Spruce $6414)$ are within the range of variation of var. macrostachyus, the exceptions being floral scale density per spikelet (S20) and angle between floral scales and rachilla (S16). A further comparison of the type materials (Spruce 6414 and Drummond 452) leads to the conclusion that there is little reason to distinguish two separate varieties. The fact that these have been distinguished may have a historical background. Variety macrostachyus was described in 1870 , when Boeckeler reduced $C$. lutescens to varietal status within C. esculentus. Later Clarke (1884) introduced var. sprucei, for the American plants with large inflorescences. At that time he still considered $C$. lutescens as a distinct species. Since var. macrostachyus was the first variety de- 
scribed, cluster 1 should have that name. This also means that, in contrast to Ter Borg et al. (1988), the Dutch biotype A should be identified as var. macrostachyus.

Cluster 2 includes three varieties, var. esculentus, var. nervoso-striatus, and var. cyclolepis. The latter was distinguished by Kükenthal (1935) because of its short and broad spikelets (Table 1); however, these characters were found to have a high level of plasticity. Since the type material (Rehmann 4776) hardly falls outside the central range of var. esculentus (Fig. 4A), we conclude that there is not enough evidence to consider var. cyclolepis varietally distinct. Plants identified as such belong to var. esculentus.

According to Kükenthal (1935), var. nervosostriatus should be distinguished because of the deviating shape of its achenes and high spikelet density (Table 1). Figure 4B shows that achene width (F10) is rather high, but it is within the range of var. esculentus. Spikelet density (E9) is distinct, and relative length of the floral scales at the top and at the base of the spikelets (G6 and G9) have deviating values. However, the most important values of the flower and floral scale characters are well within the range of var. esculentus. Therefore, there is not enough reason to distinguish var. nervoso-striatus as a separate variety.

Though they are all in one subgrouping of cluster 2 (Fig. 3B), Dutch plants of biotype C fall within this cluster, and therefore also should be identified as var. esculentus instead of var. cyclolepis as was done previously (Ter Borg et al. 1988).

Cluster 3, apart from six plants of Dutch biotype $B$, includes only two plants identified as var. heermannii, viz., the type material (Table 3, no. 68). Several characters of these plants overlap with those of other varieties, especially with var. leptostachyus. However, inflorescences of plants in this cluster have a conspicuous habit (Fig. 6D), primarily due to an extremely high spikelet density (Fig. 4E). The number of rays is often much smaller than the number of involucral bracts ( $\mathrm{C} 11)$, indicating that some spikes did not develop. In the Netherlands, plants often did not flower at all, but produced a culm with bracts only (Fig. 6E). This might have been caused by some pathogen, as in Cyperus virens Michx., where a systemic fungus was found to induce vivipary (Clay 1986). However, the plants were found to differ in other respects also, e.g., density of the erect (E8) spikelets on the axis (E9), and shape and oil content of tubers (unpubl. data). This justifies recognition at the varietal level as var. heermannii. Further study of the Dutch plants indicated that more than one genotype is involved.

As discussed under ResulTs, cluster 4 retains only plants identified as var. leptostachyus, together with the Dutch biotype D (Fig. 4D). All others have been removed for the reasons discussed.

In general, the clusters distinguished herein correspond with taxa described in previous literature. In spite of the totally different starting points of the methods, these studies resulted in similar taxonomic patterns, yielding four varieties, var. esculentus, var. leptostachyus, var. macrostachyus, and var. heermannii described by Kükenthal (1935).

Geographic Distribution of the Varieties. Variety esculentus is widespread through Africa, India, and southern Europe, and var. leptostachyus dominates northern U.S.A and Canada and the southern parts of South America. In Central America var. macrostachyus is the common variety. Variety heermannii is rare, and restricted to the southwest of the U.S.A.

Kükenthal (1935) cited only 16 sheets of American var. esculentus plants, the four we determined proved to be var. macrostachyus plants, according to their floral scale morphology. This questions whether var. esculentus is common in the America's. Most of the American material we studied could be determined as var. leptostachyus and var. macrostachyus. However, the morphology of some plants remarkably resembles that of var. esculentus. The exact distribution of var. esculentus in the America's is therefore unknown but it is probably far more rare than var. leptostachyus, and its occurrence in the America's might be caused by introduction from Europe or Africa.

The occurrence of var. leptostachyus, var. macrostachyus, and var. heermannii in Europe is probably caused by recent introductions. Varieties macrostachyus and heermannii have restricted distributions in Europe, mainly in the Netherlands, which supports the hypothesis of their recent introduction from the America's as a contaminant of Gladiolus cormlings (Ter Borg and Schippers 1992; Rotteveel 1993). Variety leptostachyus is reported in several European countries and was probably introduced into 


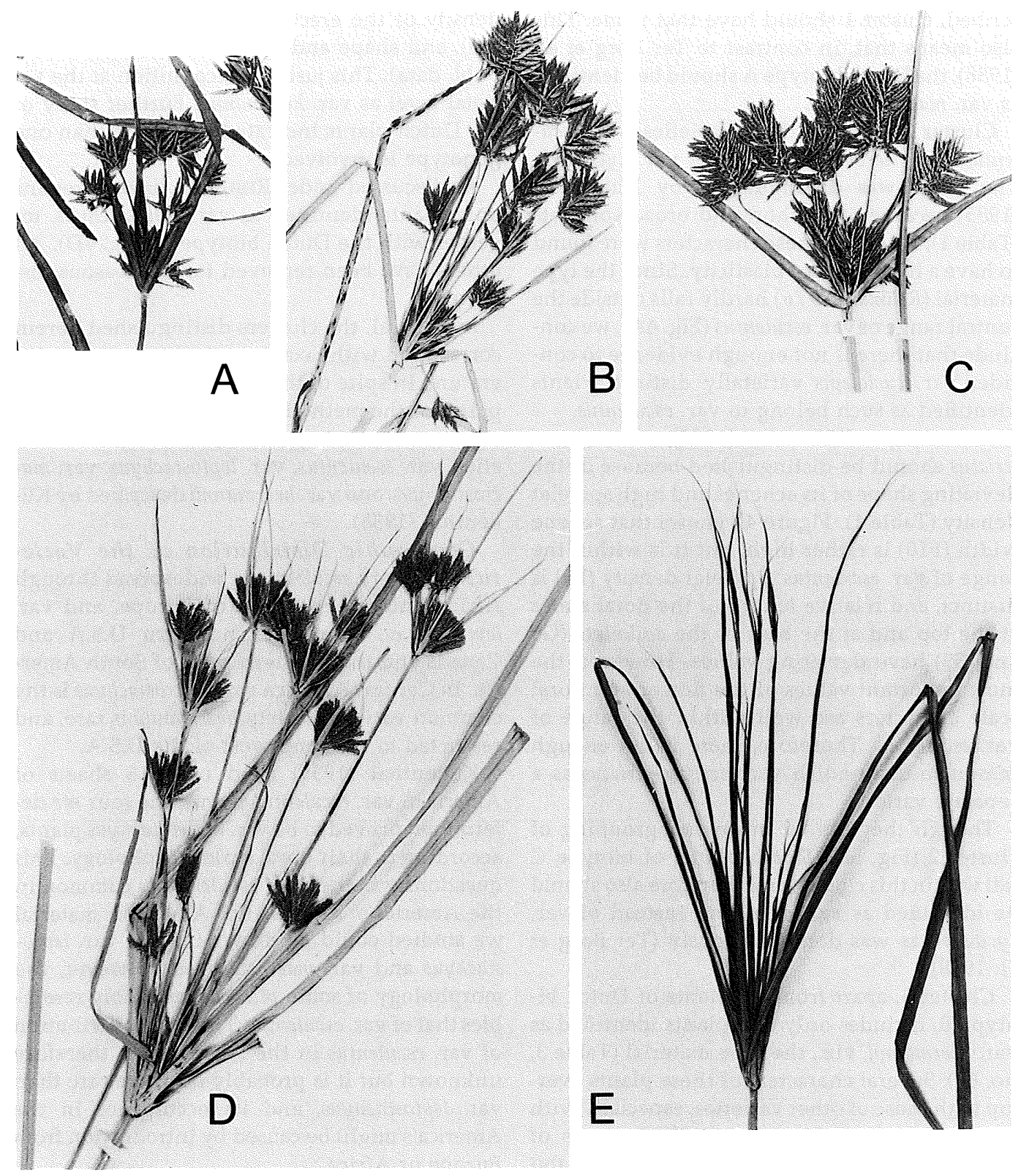

FIG. 6. Habit of inflorescences of the accepted Cyperus esculentus varieties ( $1 \frac{1}{3}$ of real size). A. Var. esculentus, Tisserant 1503 (K). B. Var. macrostachyus, De Nijs 6052 (WAG). C. Var. leptostachyus, Jörgensen 3575 (B). D. Var. heermannii, De Nijs 6910 (WAG). E. Var. heermannii, De Nijs 6712 (WAG).

France after the Second World War (Ter Borg and Schippers 1992). Variety esculentus appears to have remained within its original (southern) area of distribution in Europe (Ter Borg and Schippers 1992). Recent migrations imply that new contacts have been brought about between varieties that had been previously isolated. This may give rise to new genotypes, with intermediate morphology that can create new problems in the delimitation of the varieties.

Consequences of Plasticity. The plasticity of $C$. esculentus can have consequences for de- 
termination of specimens. The effect of the environment can change the appearance of the plant drastically. Characters like spikelet length, width, ray length, bract length, and number of rays are all plastic. Since $C$. esculentus is a cosmopolitan species, this can easily lead to a wide range of morphological forms caused by interaction between environment and the different genotypes. This makes exact determination of varieties difficult, especially intermediates between var. esculentus and var. leptostachyus. Extreme forms of $C$. esculentus can look like closely related species, but C. esculentus is always characterized by the spherically shaped tubers, $0.3-$ $1.5 \mathrm{~cm}$ in diameter, each individually developing at the end of a rhizome.

\section{Key aND TAXONOMIC TREATMENT}

The following key to the accepted varieties of $C$. esculentus is based mainly on characteristics of individual flowers because the growing experiments indicated them as the most reliable parameters for segregation of the varieties.

1. Angle between spikelets and rachis $(E 8)<35^{\circ}$, spikelet density on a spike (E9) $>2.0$ per mm; ratio of number of rays to number of bracts $(\mathrm{C} 11)<0.75$ or more than 15 flowers per spikelet ................ var. heermannii

1. Other combination of characters.

2. Mean floral scale length (G10) $\geq 3.4 \mathrm{~mm}$ ................. var. macrostachyus

2. Mean floral scale length $<3.4 \mathrm{~mm}$.

3. Mean floral scale length $(\mathrm{G} 10) \geq 2.8 \mathrm{~mm}$, and height where the floral scale reaches its maximum width (G5) $\geq 1.5 \mathrm{~mm} \ldots \ldots \ldots \ldots$. ................... var. macrostachyus

3. Floral scale length $<2.8 \mathrm{~mm}$ and height where the floral scale reaches its maximum width (G5) $<1.5 \mathrm{~mm}$.

4. Mean floral scale length (G10) $\geq 2.5 \mathrm{~mm}$, height where the floral scale reaches its maximum width (G5) $\geq 1.4 \mathrm{~mm}$, maximum floral scale width (G4) $>1.8 \mathrm{~mm}$; ratio of length of top floral scale to mean length of floral scales in the spikelet (G9) $>0.90$ or number of floral scales per spikelet $(\mathrm{S} 1) \geq 20 \quad \ldots$ var. macrostachyus

4. Other combination of characters.

5. Length of style including branches $(\mathrm{F} 1+\mathrm{F} 2)$ $\geq 4.2 \mathrm{~mm}$............... var. esculentus

5. Length of style including branches $<4.2 \mathrm{~mm}$.

6. Maximum floral scale width $(\mathrm{G} 4) \leq 1.5 \mathrm{~mm}$ ................ var. leptostachyus

6. Maximum floral scale width $>1.5 \mathrm{~mm}$.
7. Number of floral scales per spikelet (S1) $>23$ .................... var. leptostachyus

7. Number of floral scales per spikelet $\leq 23$.

8. Ratio of top floral scale length to mean length of floral scales (G9) $>0.94 \ldots$. ................. var. leptostachyus

8. Ratio of top floral scale length to mean length of floral scales (G9) $\leq 0.94$.

9. Maximum floral scale width (G4) $\leq 1.8 \mathrm{~mm}$ and length of style $(\mathrm{F} 1+\mathrm{F} 2) \leq 3.4 \mathrm{~mm} \ldots \ldots$. .................... var. leptostachyus

9. Maximum floral scale width $>1.8 \mathrm{~mm}$ and length of style $>3.4 \mathrm{~mm}$.

10. Maximum floral scale width $(\mathrm{G} 4) \leq 1.9 \mathrm{~mm}$, mean floral scale length (G10) $\leq 2.3 \mathrm{~mm}$ and anther length (F6) $\leq 1.4 \mathrm{~mm} \ldots$... ................. var. leptostachyus

10. Higher character values.

11. Maximum floral scale width (G4) $\leq 2.0 \mathrm{~mm}$, mean floral scale length $(\mathrm{G} 10) \geq 2.6 \mathrm{~mm}$; length of style (F1 + F2) $\leq 3.5 \mathrm{~mm}$ or angle between floral scale and spikelet axis (S16) $<17^{\circ} \ldots \ldots \ldots \ldots \ldots \ldots$ var. leptostachyus 11. Other combination of characters ... var. esculentus

After a general characterization of $C$. esculentus, descriptions are given for the four varieties accepted. These are primarily based on the clusters resulting from the numerical analysis and the parameters included. Ranges indicated are based on the average values plus or minus one standard deviation. Further details are given in Table 6 . Relevant characters mentioned by other authors have been included, as far as their relation with the variety is consistent. This concerns characters of spikelets and tubers.

CYPerus esCulentus L. Sp. Pl. ed. 1: 45. 1753.TYPE: Morison, Pl. hist. univ. vol. 3, sect. P, t. 11 , no. $8\left[{ }^{\prime \prime} 10^{\prime \prime}\right], 1699$, lectotype, designated by Tucker (1994).

Perennial often weedy plants with usually long fleshy rhizomes producing new shoots or with one persistent tuber at the end. Leaves $70(-$ 120) $\mathrm{cm}$ long and up to $10 \mathrm{~mm}$ wide, linear, clustered, pale green. Culm up to $60(-100) \mathrm{cm}$ long, triangular, ending in an inflorescence with $5-11,10-50 \mathrm{~cm}$ long bracts around a number of spikes; the primary spike is almost sessile, the others are up to $25 \mathrm{~cm}$ long, usually half the length of the corresponding bract, pedunculate. Spikes, sometimes compound, with 2nd order branches, and up to $30(-50)$ spikelets. Spikelets compressed, 5-30(-55) $\mathrm{mm}$ long and 1-3 mm wide. Scales yellow-brown, (1.5-)2.0-3.3(-4.5) 
TABLE 6. Mean values, standard deviation (s.d.) and minimum and maximum values observed in the varieties of Cyperus esculentus measured (Dutch plants not included). The underlined values indicate the most discriminating characters; see Table 2 for their more detailed description.

\begin{tabular}{|c|c|c|c|c|c|c|c|c|c|c|c|c|c|}
\hline $\begin{array}{c}\text { Character } \\
\text { desig- } \\
\text { nation }\end{array}$ & \multicolumn{4}{|c|}{$\begin{array}{l}\text { var. macrostachyus } \\
N=13\end{array}$} & \multicolumn{4}{|c|}{$\begin{array}{c}\text { var. esculentus } \\
N=19\end{array}$} & \multicolumn{4}{|c|}{$\begin{array}{l}\text { var. leptostachyus } \\
N=10\end{array}$} & $\begin{array}{c}\text { var. heermannii } \\
N=3\end{array}$ \\
\hline F1 & 2.0 & 2.95 & 4.0 & 0.60 & 2.0 & 2.81 & 4.5 & 0.66 & 1.2 & 1.83 & 2.5 & 0.48 & 1.56 \\
\hline F2 & 0.9 & 1.64 & 2.2 & 0.36 & 0.6 & 1.37 & 2.2 & 0.43 & 0.7 & $\overline{0.99}$ & 1.2 & 0.18 & 0.93 \\
\hline F6 & 1.2 & 1.69 & 2.1 & 0.33 & 1.0 & 1.57 & 2.1 & 0.32 & 1.0 & 1.26 & 1.6 & 0.17 & 1.23 \\
\hline G10 & 2.8 & 3.17 & 3.5 & 0.24 & 2.0 & 2.52 & 3.4 & 0.31 & 1.8 & 2.23 & 2.7 & 0.26 & 2.52 \\
\hline G4 & 1.8 & $\overline{2.09}$ & 2.4 & 0.17 & 1.6 & $\overline{1.93}$ & 2.4 & 0.25 & 1.5 & $\overline{1.62}$ & 1.9 & 0.16 & 1.70 \\
\hline G6 & 0.99 & 1.05 & 1.13 & 0.04 & 0.93 & $\overline{1.13}$ & 1.26 & 0.08 & 0.93 & 1.04 & 1.11 & 0.07 & 1.05 \\
\hline S1 & 6 & $\underline{21.6}$ & 42 & 13.6 & 6 & 11.4 & 19 & 4.0 & 5 & 12.7 & 20 & 5.4 & 13.3 \\
\hline $\mathrm{S} 20$ & 1.04 & $\overline{1.24}$ & 1.59 & 0.15 & 0.92 & 1.45 & 2.00 & 0.30 & 1.11 & 1.32 & 1.66 & 0.17 & 1.37 \\
\hline S16 & 13.0 & 17.4 & 23.0 & 3.4 & 15.0 & 22.5 & 28.0 & 4.3 & 11.0 & 16.3 & 24.0 & 4.1 & 22.0 \\
\hline S11 & 0.75 & 0.95 & 1.26 & 0.13 & 0.72 & $\overline{0.99}$ & 1.22 & 0.13 & 0.63 & 0.86 & 1.11 & 0.14 & 1.08 \\
\hline E6 & 0 & 1.8 & 4 & 1.5 & 0 & 1.6 & 4 & 1.4 & 0 & 2.3 & 3 & 1.32 & 1.33 \\
\hline
\end{tabular}


A

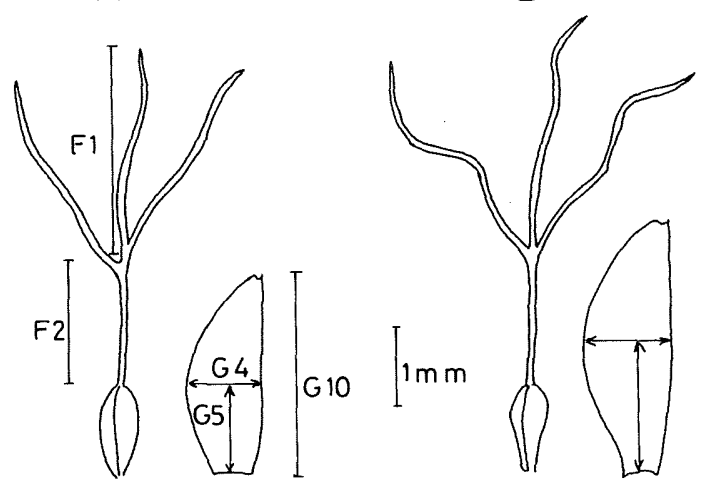

C

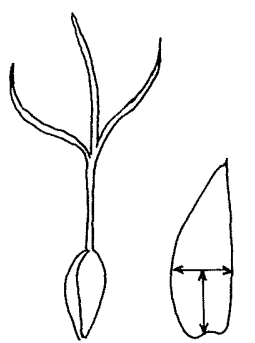

D

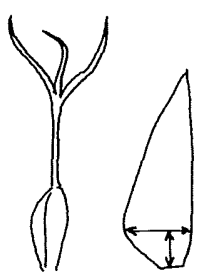

FIG. 7. Characteristics of floral scales, ovaries, and styles of four Cyperus esculentus varieties according to average values of Table 6. A. Var. esculentus. B. Var. macrostachyus. C. Var. leptostachyus. D. Var. heermannii.

$\mathrm{mm}$ long and 1.4-2.4 $\mathrm{mm}$ wide, obtuse and sometimes slightly mucronulate, with 2-3 distinct veins, which can be reddish. Rachilla with adnate hyaline scales. Ovary 1-1.2 mm long and 0.3-0.6 mm wide, pale green. Achene 1.2-1.6 $\mathrm{mm}$ long and $0.5-0.8 \mathrm{~mm}$ wide, triangular, ellipsoid or narrowly obovoid, smooth, bright grey-brown. Anthers 1.0-2.1 mm long. Style (0.6-) $0.8-2.0(-2.2) \mathrm{mm}$ long, with three stigmata, length (1.2-)1.4-3.5(-4.5) $\mathrm{mm}$.

CYPERUS ESCULENTUS L. var. ESCULENTUS

C. esculentus var. cyclolepis Boeck. ex Kük. (syn. nov., here designated), Kükenthal, Engl. \& Diels, Pflanzenr. IV. 20: 119. 1935.-TYPE: S. Africa, Pretoria, Rehmann 4776 (lectotype: $\mathrm{B}$ !, isolectotype:K!), Thomas 113 (paratype: not seen).

C. esculentus var. nervoso-striatus (Turrill) Kük. (syn. nov., here designated), Kükenthal Engl. \& Diels, Pflanzenr. IV. 20: 119. 1935. Basionym: C. nervoso-striatus Turrill, Kew Bull. 1925: 68. 1925.-TYPE: S. Africa, Ermelo; Burtt Davy 9237 (holotype: PRE!).

Synonyms according to Kükenthal (1935): C. aureus Ten., C. melanorrhizus Delile, C. hydra Humb., Bombl. \& Kunth, C. nervosus, Roem. \& Schult., C. tenorii C. Presl, C. tenorianus Roem. \& Schult., C. sieberianus Link, C. pallidus Savi, C. damiettensis A. Dietr., C. retusus Nees, C. scirpoides R.Br. ex Hochst., C. buchananii Boeck., C. esculentus L. var. aureus K. Richt., C. fezelianus C.B. Clarke, Chlorocyperus aureus Palla.

Tubers up to $10 \mathrm{~mm}$ long. Inflorescence sim- ple to complex, rays usually with flowering spikes, and numerous (up to 2 per $\mathrm{mm}$ ) flowers per spikelet. Spikelets 5-20 $\mathrm{mm}$ long and up to ca. $2 \mathrm{~mm}$ wide, sometimes short and then more or less obovoid. Flower size intermediate. Floral scales (2.0-)2.2-2.9(-3.4) $\mathrm{mm}$ long and (1.6-)1.72.2(-2.4) $\mathrm{mm}$ wide; their maximum width at $(0.8$ )1.0-1.5(-1.8) $\mathrm{mm}$ above the base. Anthers (1.0)1.2-1.9(-2.1) mm. Style (0.6-)0.9-1.8(-2.2) mm long, stigma (2.0-)2.2-3.5(-4.5) mm. (Figs. 4A, $\mathrm{B}, 6 \mathrm{~A}, 7 \mathrm{~A}$ )

Distribution. S. Europe, Asia and Africa; 1ocally in northern areas of North America.

Vouchers. Table 3 numbers: 50-67, 90 and De Nijs 7020, 7415, 7417 (WAG).

CYPERUS ESCULENTUS L. var. MACROSTACHYUS Boeckeler, Linnaea 36: 291. 1870. Kükenthal, Engl. \& Diels, Pflanzenr. IV. 20: 121. 1935.-TYPE: U.S.A., Texas, Drummond 452 (holotype: $\mathrm{B} !$; isotype: $\mathrm{BM} ! \mathrm{K} !)$.

C. esculentus var. sprucei Clarke (syn, nov. here designated), J. Linn. Soc., Bot. 21: 181. 1884.-TYPE: Ecuador, Chanduy, Spruce 6414 (holotype: $\mathrm{K} !)$.

Synonyms according to Kükenthal (1935): C. lutescens Torr. \& Hook., C. ruficomus Buckley, C. esculentus var. lutescens (Torr. \& Hook.) Kük.

Tubers up to $15 \mathrm{~mm}$ long (in the Netherlands). Inflorescence simple, rays usually with flowering spikes, many spikelets per spike. Spikelets up to $40 \mathrm{~mm}$ long and $3 \mathrm{~mm}$ wide. Large floral scales, (2.7-)2.9-3.4(-3.6) $\mathrm{mm}$ long 
and (1.8-)1.9-2.3(-2.4) mm wide, at (1.0-)1.3$1.9(-2.0) \mathrm{mm}$ from the base. Anthers (1.2-)1.3$2.0(-2.1) \mathrm{mm}$ long. Style $(0.9-) 1.3-2.0(-2.2) \mathrm{mm}$ long, stigma (2.0-)2.3(-4.0) mm long. (Figs. $4 C_{\text {, }}$ $6 \mathrm{~B}, 7 \mathrm{~B})$

Distribution. Southern parts of U.S.A., C. America; recently found in the Netherlands.

Vouchers. Table 3 numbers: 1, 5, 70, 71, 72, 73, $79,80,81,84,85,86,89$.

CYPERUS ESCULENTUS L. var. LePtostachyUS Boeckeler, Linnaea 36: 290. 1870. Kükenthal in Engl. \& Diels, Pflanzenr. IV.20: 119. 1935, excluding Curtiss 3052 (US!, K!), Ekman 14084 (K!), Palmer 6454 (US!) all C. esculentus var. macrostachyus. - TYPE: U.S.A. Pennsylvania, Willd. herb. no. 1377 (holotype: B-W, n.v., photo!).

Synonyms according to Kükenthal (1935): C. phymatodes Mühlenb., C. tuberosus Pursh, C. nervosus Bertol., C. gracilis Link, C. repens Elliott, $C$. gracilescens Roem. \& Schult., C. rotundus Benth. non L., C helodes Schrad. ex Nees, C. cubensis Steud., C. bahiensis Steud. ,C. fulvescens Liebm., C. chrysostachys Boeck., C. esculentus L. var angustispicatus Britton, Chlorocyperus phymatodes (Mühlenb.) Palla, C. esculentus L. var. phymatodes (Mühlenb.) Kük

Tubers up to $10 \mathrm{~mm}$ long. Inflorescence simple, rays usually with flowering spikes. Secondorder rays with up to 8 third-order rays. Spikelets $15-20 \mathrm{~mm}$ long and up to $1.5-2.0 \mathrm{~mm}$ wide. Flowers generally small; floral scales (1.8-)1.92.5(-2.7) $\mathrm{mm}$ long and $1.5-1.8(-1.9) \mathrm{mm}$ wide, mucronate. Anthers (1.0-)1.3(-1.6) mm. Style $(0.7-) 1.0(-1.2) \mathrm{mm}$ long, stigma (1.2-)1.8(-2.5) mm long. (Figs. $4 \mathrm{D}$ and $6 \mathrm{C}, 7 \mathrm{C}$ )

Distribution. N. and S. America, W. Europe (probably introduced around 1947).

Vouchers. Table 3 numbers: 3, 7, 74-78, 82, 83, 87, 88, and De Nijs 7407 \& 7418 (WAG).

CYPERUS ESCULENTUS var. HEERMANNII Torrey, Bot. Club XIII: 210. 1886. Kükenthal, Engl. \& Diels, Pflanzenr. IV.20: 120. 1935. Basionym: C. heermannii Buckley, Proc. Acad. Sci. Philadelphia: 10. 1862, Boeckeler, Linnaea 36: 287. 1870.-TYPE: U.S.A., California, Heermann 31882 (holotype: US!).
Tubers up to $10 \mathrm{~mm}$. Inflorescence may be compound, with primary and secondary bracts at each level of branching, however, rays and flowers often do not develop, leaving the plants vegetative. Spikes with suberect (angle $<40^{\circ}$ ) spikelets close to each other on the rachis $(>2$ per $\mathrm{mm}$ ). Spikelets sometimes very long (up to $55 \mathrm{~mm}$ ) and up to $3 \mathrm{~mm}$ wide. Flowers small, floral scales short, ca. $2.5 \mathrm{~mm}$ long and $1.7 \mathrm{~mm}$ wide, maximum width well below the middle of the floral scale; anthers $1.2 \mathrm{~mm}$, style $0.9 \mathrm{~mm}$ and stigma $1.6 \mathrm{~mm}$ long. (Figs. 4E, 6D, E, 7D)

Distribution. South eastern parts of the United States; recently introduced into the Netherlands.

Vouchers. Table 3 numbers: 2, 68, 69, and De Nijs $3540,7005 \& 7018$ (WAG).

ACKNOWLEDGMENTs. Thanks are due to Dr. P. G. Goetghebeur (Gent) and Prof. Dr. Ir. L. J. G. Van der Maesen for their comments on the manuscript, to members of the Photographic Department "Binnenhaven" and Mr. H. M. Klees, for preparing Figs. 6 and 7 respectively. Furthermore we thank three anonymous reviewers and Dr. Gerald J. Gastony for their detailed comments and editorial help. We thank all herbaria making their materials available for this study: $\mathrm{B}, \mathrm{BM}, \mathrm{K}, \mathrm{L}, \mathrm{MO}, \mathrm{PRE}$, and US.

\section{LITERATURE CITED}

Ascherson, P. F. A. and K. O. R. P. P. Graebner 1902-1904. Synopsis der Mitteleuropäischen Flora, Vol. 2. Leipzig: Verlag von Wilhelm Engelmann.

BENDIXEN L. E. and U. B. NANDIHALli. 1987. Worldwide distribution of purple and yellow nutsedge (Cyperus rotundus and C. esculentus). Weed Technology 1: 61-65.

BoECKELER, J. 1870. Die Cyperaceeen des königlichen Herbariums zu Berlin. Linnaea 36: 287-291.

BRITTON N. L. 1886. Preliminary list of North American species of Cyperus, with description of new forms. Bulletin of the Torrey Botanical Club 13: 205-216

CAVERS, P. B. 1985. Intractable weeds: Intraspecific variation must be considered in formulating control measures. Pp. 367-376 in Proceedings of the Brighton crop protection conference weeds 1985. Farnham, Surrey: British Crop Protection Council.

Clarke, C. B. 1884. On the Indian species of Cyperus. Journal of the Linnean Society London 21: 178 181.

CLAX, K. 1986. Induced vivipary in the sedge Cyperus virens and the transmission of the fungus Balansia cyperi (Clavicipitaceae). Canadian Journal of Botany 64: 2984-2988. 
CostA, J. and A. P. Appleby. 1976. Response of two Yellow Nutsedge varieties to three herbicides. Weed Science 24: 54-58.

DE VRIES, F. T. 1991. Chufa (Cyperus esculentus, Cyperaceae): a weedy cultivar or a cultivated weed? Economic Botany 45: 27-37.

FERNALD, M. L. 1950. Gray's manual of botany, 8th Edition. New York: American Book Company.

HAUSER, E. W. 1968. Yellow Nutsedge-problems, research trends and outlook. Proceedings of the Northeastern Weed Control Conference 22: 3748.

Holm, L. G., D. L. PluCKNetT, J. V. PANCH, and J. P. HERBERGER. 1977. The world's worst weeds: Distribution and biology. Honolulu: Univ. Press.

HoRAK, M. J. and J. S. HolT. 1986. Isozyme variability and breeding systems in populations of yellow nutsedge (Cyperus esculentus). Weed Science 34: 538-543.

KÜKENTHAL, G. 1935. Cyperaceae-Scirpoideae-Cypereae. Pp. 116-121 in Das Pflanzenreich IV-20 eds. A. Engler and L. Diels. Leipzig: Verlag von Wilhelm Engelmann.

MATthiesen, R. L. and E. W. StolleR. 1978. Tuber composition in yellow nutsedge (Cyperus esculentus L.) variants. Weed Research 18: 373-377.

MOHLENBROCK, R. H. 1960. The Cyperaceae of Illinois. 1. Cyperus. American Midland Naturalist 63: 270-306.

RotTeVEeL, A. J. W. 1993. Tien jaar Knolcyperus (Cyperus esculentus L.) in Nederland (Ten years Yellow Nutsedge in the Netherlands). Gorteria 19: 65-73. (in Dutch with English summary)

SAS INSTITUTE INC. 1985. SAS user's guide: Statistics, Version 5 Edition. Cary, North Carolina: SAS Institute Inc.

SChIPPERS, P., S. J. Ter Borg, J. M. VAN GRoENENDAel, and B. НАвEKOTTÉ. 1993. What makes Cyperus esculentus (Yellow Nutsedge) an invasive spe-
cies?-A spatial model approach. Pp. 495-504 in Proceedings of the Brighton crop protection conference weeds 1993. Farnham, Surrey: British Crop Protection Council.

SteYkRMARK, J. A. 1963. Cyperaceae. Pp. 255-273 in Flora of Missouri. Iowa: Iowa State Univ. Press.

Stoller, E. W. and R. D. SWeEt. 1987. Biology and life cycle of Purple and Yellow Nutsedges (Cyperus rotundus and C. esculentus). Weed Technology 1: 66-73.

Ter Borg, S. J., L. J. De Nijs, and H. Van Oene. 1988. Intraspecific variation of Cyperus esculentus $\mathrm{L}$. in the Netherlands; a preliminary report. Pp. 181185 in VIIIème colloque international sur la biologie des mauvaises herbes. Paris: Association Nationale pour la Protection des Plantes.

and P. SCHIPPERS. 1992. Distribution of varieties of Cyperus esculentus L. (Yellow Nutsedge) and their possible migration in Europe. Pp. 417425 in IXème colloque international sur la biologie des mauvaises herbes. Paris: Association Nationale pour la Protection des Plantes.

TUCKER, G. C. 1994 Revision of the Mexican species of Cyperus (Cyperaceae). Systematic Botany Monographs 43: 1-213.

VAN GROENENDAEL, J. M. and B. HABEKOTtÉ. 1988. Cyperus esculentus L. biology, population dynamics and possibilities to control this neophyte. Zeitschrift für Pflanzenkrankheiten und Pflanzenschutz, Sonderheft XI: 61-69.

YIP, C. P., 1978a. Yellow Nutsedge (Cyperus esculentus L.) ecotypes, their characteristics and responses to environment and herbicides. Ph.D. Dissertation, Cornell University, Ithaca, New York.

- 1978b. Yellow Nutsedge (Cyperus esculentus L.) ecotypes, their characteristics and responses to environment and herbicides. Dissertation $\mathrm{Ab}$ stracts 39: 1562. 